\title{
THE POTENTIAL OF FOREST HONEY (Apis spp.) FROM TIMOR ISLAND AS ANTIBACTERIAL AGAINST PATHOGENIC BACTERIA IN FISH CULTURE
}

\author{
Yuliana Salosso" \\ Faculty of Marine and Fisheries, Nusa Cendana University \\ Jl. Adisucipto, Penfui Kupang 85001, Nusa Tenggara Timur
}

(Received 11 March 2019; Final revised 10 May 2019; Accepted 10 May 2019)

\begin{abstract}
This study aims to assess the potential of forest honey Apis spp. from Timor Island as an antibacterial on pathogenic bacteria, Aeromonas hydropilla and Vibrio alginolyticus in cultured fish. There were six types of honey tested in this study of which active compound, total glucose, $\mathrm{pH}$, and water content of each honey were determined. The chemical contents of the honey were examined for alkaloid using Culvenor-Fitzgerald method, saponin with foam test, terpenoid and steroid with Lieberman-Burchard method, tannin with addition of $\mathrm{FeCl}_{3}$, and flavonoid addition of $\mathrm{HCl}$ and $\mathrm{Mg}$ powder. Total glucose was measured using spectrophotometer, water content with gravimetry, and $\mathrm{pH}$ with $\mathrm{pH}$-meter. The antibacterial activity test of the honey was done using disc method without dilution. Results showed that all forest honey from Timor Island contained alkaloid, saponin, steroid, and terpenoid, except Kefa honey which did not have steroid and terpenoid. The water content of the honey ranged from $15.70 \%$ to $26.65 \%$ total glucose of $71.16 \%$ to $80.58 \%$ and $\mathrm{pH}$ of 3.84 to 4.06 . The forest honey also had antibacterial activity against A. hydropilla and $\mathrm{V}$. alginoliticus with different inhibition zones.
\end{abstract}

\section{KEYWORDS: Aeromonas hydropilla; antibacterial; honey; Vibrio alginolyticus}

\section{INTRODUCTION}

Honey is a viscous liquid produced by honey bees from flower nectar (Yuliati, 2017). Based on the nectar source, honey can be distinguished as monoflora and polyflora. The former is produced from one major plant and the latter from the nectar of several types of plants. Forest honey is a polyflora one produced by wild bees Apis dorsata. These bees usually live in the forest and depend their various food sources from forest plants such as flower nectar or tree sap. Due to diverse food sources, the honey has better quality due to honey content of more complex compounds. Forest honey produced by the wild bees is also very good for health since it contains natural antibiotics.

Several studies have proved the potential of the forest honey from Indonesia as an antibacterial against pathogenic Gram-positive or Gram-negative bacteria in human. Yuliati (2017) did an in vitro study which revealed the antibacterial superiority of forest

\footnotetext{
\# Correspondence: Faculty of Marine and Fisheries, Nusa Cendana University. Jl. Adisucipto, Penfui Kupang 85001, Nusa Tenggara Timur, Indonesia Phone: + 62911379196

E-mail: yulimarasin@gmail.com
}

honey from Sumbawa against bacteria Staphylococcus aureus and Pseudomonas aeruginosae. Honey from Bandung and Riau Islands have also been proved to have antibacterial activity against Staphylococcus aureus and Escherichia coli (Dewi et al., 2017). Furthermore, bitter and sweet black honey (forest honey from Kalimantan) has antibacterial activity against E. coli and S. aureus (Fitrianingsih et al., 2014).

Honey has been studied for its applications as a pathogenic antibacterial in human. Nevertheless, reports on its utilization as antibacterial in fish culture is currently limited. Considering the antibacterial feature of the honey, Testing the antibacterial activity of forest honey against Aeromonas hydropilla and Vibrio alginolyticus infecting cultured fish is a researchable topic. Salosso (2017) tried to study the antibacterial activity of Timorese honey from Soe against A. hydropilla and V. alginolyticus and its active compounds. Her finding revealed that the honey from Soe contained active compounds such as flavonoid, triterpenoid, and saponin. The compounds can inhibit the growth of A. hydrophilla and V. alginolyticus in all tested concentrations. However, this study was only limited to the forest honey from Soe and not from other places. 
Timor Island is one of the large islands in East Nusa Tenggara Province, Indonesia. The forest on the island is known to produce high-quality forest honey, such as forest honey from Soe, Kefa, Ampang, South Ampang, Naikliu, and others. The forest honey from Timor Island is mostly traditionally produced by the local communities and has not been studied about their chemical contents and natural benefits. This study assessed the potential of forest honey Apis spp. from Timor Island as antibacterial on pathogenic bacteria, Aeromonas hydropilla and Vibrio alginolyticus in cultured fish.

\section{MATERIALS AND METHODS}

\section{Honey Collection}

Forest honey was purchased from honey retailers who bought the honey from local honey finders originated from three regencies in Timor Island: North Central Timor (Kefa), South Central Timor (Soe), and Kupang Regency (Ampang, South Ampoang, and Naikliu). Commercial honey, madu rasa, was used as a comparison honey. The paper disc containing 30 $\mu \mathrm{g}$ of nobiocin antibiotic was used as a control.

\section{Phytochemical Analysis}

\section{Alkaloid test}

Honey sample of $2 \mathrm{~mL}$ was mixed with $3 \mathrm{~mL}$ of chloroform and three drops of ammonia. The chloroform fraction was separated and acidified in 10 drops of $2 \mathrm{~N} \mathrm{H}_{2} \mathrm{SO}_{4}$. Sulphuric acid $\left(\mathrm{H}_{2} \mathrm{SO}_{4}\right.$ fraction was taken and added with Dragendroff reagent. The presence of alkaloid was indicated with formation of brownish (reddish) orange deposition (Hanani, 2014).

\section{Saponin test}

Honey sample of $2 \mathrm{~mL}$ was put into a flask, then mixed with $10 \mathrm{~mL}$ of distilled water, boiled for 2-3 min, and then cooled. Afterwards, the solution was shaken vigorously for $10 \mathrm{~min}$. Formation of stable foam after 10 min indicated the presence of saponin (Hanani, 2014).

\section{Triterpenoid and steroid test}

Honey sample was dropped on the drop plate and added with Lieberman-Buchardt reagent. Presence of terpenoid indicated by the red color formation or steroid with green color (Hanani, 2014).

\section{Tannin test}

Honey sample of $2 \mathrm{~mL}$ was boiled for several mins., then added with 2-3 drops of $1 \% \mathrm{FeCl}_{3}$. The presence of tannin was indicated by a dark blue or greenishblack color (Hanani, 2014).

\section{Flavonoid test}

Honey sample of $2 \mathrm{~mL}$ was extracted in $5 \mathrm{~mL}$ of methanol. The filtrate was then added with two drops of $2 \mathrm{~N} \mathrm{HCl}$ and strongly shaken, added with magnesium powder, and strongly re-shaken. Flavonoid was indicated by a high intensity of foam and the solution changes to yellow-orange or dark red (Hanani, 2014).

\section{Analysis of pH, Water Content, and Honey}

$\mathrm{pH}$ was determined using a $\mathrm{pH}$-meter, total glucose measurement used spectrophotometer, and water content of the honey used gravimetry.

\section{Antibacterial Test of the Honey}

\section{Solid and semi-solid TSA media preparation}

Media used for the growth of bacteria A. hydropilla used trypticase soy agar (TSA) with addition of $0.5 \%$ $\mathrm{NaCl}$ and $\mathrm{V}$. alginolitycus used TSA media with addition of $2 \% \mathrm{NaCl}$. These media were used for antibacterial test and made two layers, solid TSA, and semisolid TSA. The former had been made a day before the antibacterial test was done using the TSA as labeled, while the latter was made at the time the test was done using $70 \%$ TSA as labeled.

The solid TSA was autoclaved and poured into a petri dish as much as $10 \mathrm{~mL}$ and left up to solid and kept in the refrigerator in an upside-down position. The semi-solid media were autoclaved and cooled down to $50^{\circ} \mathrm{C}$, then added with $\mathrm{A}$. hydropilla on $0.5 \%$ TSA media and V. alginolitycus on 2\%TSA at a density of $10^{6} \mathrm{cell} / \mathrm{s} / \mathrm{mL}$, and each of them was poured as much as $10 \mathrm{~mL}$ into the solid TSA, then left down frozen. Afterward, it was ready to do the disc test (Salosso, 2017).

\section{Disc Test for Antibacterial of Honey}

The sterile paper disc was dipped into the original honey (without dilution). After 30 minutes, the disc paper was attached to the TSA media inoculated with $A$. hydropilla and $V$. alginolitycus. Measurements were done after 24 -hour inoculation at $37^{\circ} \mathrm{C}$ by observing whether clear zone occurs around the paper disc or not.

\section{RESULTS AND DISCUSSION}

\section{The Active Compound of the Honey}

Qualitative test of the active compounds of the honey from Timor Island is presented in Table 1. This study demonstrates that all forest honey from Timor Island contain alkaloid, saponin, and steroid and terpenoid, except Kefa honey which does not contain steroid and terpenoid. 
Commercial honey contains only alkaloid. The active compound content of the forest honey from Timor Island is not quite different from that of forest honey from Aceh, Seulawah (Aceh Besar) and Trumon (South Aceh) which also contains saponin and terpenoid, but no alkaloid and steroid (Fadhmi et al., 2015). However, Forest honey from Timur Island has different active compound compared to Nigerian honey which did not contain alkaloid and saponin, but contain tannin and flavanoid (Adeyemo et al., 2017).

The chemical compounds of the forest honey from Soe in this study contained an alkaloid, steroid, terpenoid, and saponin. In fact, different from those found by Salosso (2017) which were only flavonoid, triterpenoid, and saponin. This evidence reflects that active compound content of the honey might be influenced by seasons as both types of forest honey from Soe were collected from the same locality but at different times. Francois et al. (2017) also found similar result where honey from Benin Republic holds alkaloid, tannin, and flavonoid in dry season, and alkaloid, tannin, flavonoid, and terpenoid and steroid in rainy season.

The difference in active compounds content of the honey could be the result pf different nectars taken by different bees (Ma'ruf et al., 2018). Moreover, Parwata et al. (2010) stated that honey had different composition of chemical compounds based on the food/nectar sources of the bee. This difference could result in different antibacterial activity of the honey.

\section{Water Content, pH, and Total Glucose}

Total sugar, water content, pH of the honey from Timor Island is provided in Table 2.

\section{Water Content}

The water contents in the forest honey from Timor Island were ranged from $15.70 \%$ to $26.65 \%$ (Table 2). This content was the highest compared to that of found by Nadhila (2014) of 15\%21\% Ampoang honey had the lowest water content of $15.70 \%$ which was lower than that of the commercial one since this honey has had water reduction process and well packed in sales. Honey from Kefa, Naikliu, South Ampoang, and Soe have not been treated for water reduction process so that it has higher water content than the commercial one.

The water content of honey could be different with different localities. Honey water content of rubber tree nectar from Central Bangka Regency was $24.25 \%$ (Evahelda et al., 2017), while the water contents of Trumon and Seulawah honey from Aceh were $22.05 \%$ and $19.81 \%$ (Fadhmi et al., 2015), respectively. The water contents of bitter and sweet black honey from Central were $16.19 \%$ and $15.40 \%$ (Fitrianingsih et al., 2014), respectively. In general, the water content of some types of honey from Indonesia ranged from $17.8 \%$ to $21.0 \%$ (Dewi et al., 2017). The difference in the water content of the honey is affected by several factors, such as climate, post-harvest handling, nectar type collected, honey maturity, production techniques, and storage (Baroni et al., 2009).

\section{Total Glucose}

Honey holds high total sugar, and dominantly consists of glucose and fructose (Nayik \& Nanda, 2015). Forest honey from Timor Island has high total sugar, $71.16 \% 80.58 \%$ Total sugar content of Timorese honey was not quite different from the total sugar content of honey from rubber tree nectar of Central Bangka regency, $74.77 \%$ (Evahelda et al., 2017). Honey has also different chemical compounds, including total sugar based upon food source of the nectar (Parwata et al., 2010).

According to Evahelda et al. (2017), the high sugar content will make the honey to be more viscous or concentrated so that it has hygroscopic feature. This honey characteristic is determined by fructose since fructose is more soluble than glucose (Buba et al.,

Table 1. Active compounds in forest honey from Timor Island

\begin{tabular}{lcccccc}
\hline \multirow{2}{*}{ Honey types } & \multicolumn{7}{c}{ Active compound tests } \\
\cline { 2 - 7 } & Flavonoid & Alkal oid & Steroid & Terpenoid & Tanin & Saponin \\
\hline Kefa honey & - & + & - & - & - & + \\
Ampoang honey & - & + & + & + & - & + \\
Naikliu honey & - & + & + & + & - & + \\
South Ampoang honey & - & + & + & + & - & + \\
Soe honey & - & + & + & + & - & + \\
Commercial honey & - & + & - & - & - & - \\
\hline
\end{tabular}


Table 2. Percentages of water content and total glucose and pH level of forest honey from Timor Island

\begin{tabular}{lccc}
\hline \multicolumn{1}{c}{ Honey types } & Water (\%) & Total glucose (\%) & pH \\
\hline Honey from Kefa & 26.65 & 72.60 & 4.06 \\
Honey from Ampoang & 15.70 & 80.58 & 3.95 \\
Honey from Naikliu & 26.65 & 71.16 & 4.00 \\
Honey from South Ampoang & 23.02 & 75.2 & 3.85 \\
Honey from Soe & 23.52 & 74.37 & 3.84 \\
Commercial honey & 21.18 & 78.53 & 3.87 \\
\hline
\end{tabular}

2013). Moreover, according to Erguder et al. (2008), sugar content of honey consisting of mixture of glucose and fructose causes the honey to osmotic feature and can inhibit bacterial growth.

\section{Honey pH}

The $\mathrm{pH}$ of forest honey from Timor Island ranged from 3.84 to 4.06 . This range tends to be the same as that of from other places in Indonesia, such as randu honey with $\mathrm{pH}$ of 3.8 , rambutan honey with $\mathrm{pH}$ of 4.21 , longan honey with $\mathrm{pH}$ of 4.48 , kaliandara honey with $\mathrm{pH}$ of 4.37 (Chayati, 2008), and rubber tree honey from Bangka, 3.92 (Evahelda et al., 2017). Similarly, honey from India has $\mathrm{pH}$ of 4.1 (Veeraputhiran et al., 2013).

Despite having a similar $\mathrm{pH}$ range, there is a difference in honey $\mathrm{pH}$ among honey from Timor Island. This difference could result from differences in mineral and acid content of the honey (Gulfraz et al., 2010). According to Buba et al. (2013), the mineral content of the honey is influenced by soil condition, geographic position, climatic condition where the nectar source plants grow.

Honey of low pH can inhibit the growth of various bacteria since bacteria can grow in neutral or alkaline $\mathrm{pH}$ conditions. Acidity gives high impact on the growth and the survival of bacterial cells. Each species has an optimum range of acidity for growth. When $\mathrm{pH}$ declines to the lowest limit for bacterial growth, not only bacterial cells stop growing, but the bacteria will lose their ability to survive as well.

\section{Antibacterial Activity}

Antibacterial test of the forest honey from Timor Island against V. alginoliticus and A. hyropilla can be seen in Figure 1. It is apparent that all types of forest honey from Timor Island possess antibacterial activity against $A$. hydropilla and $V$. alginoliticus, but the diameters of inhibition zone are different.
Against V. alginoliticus, the inhibition zones of all honey types from Timor Island were all higher than that of commercial honey, madu rasa (11 mm), except that south Ampoang honey has lower inhibition zone $(9 \mathrm{~mm})$. All these inhibition zones are still lower than that of antibiotics $(22.5 \mathrm{~mm})$. Similarly, against A. hydropilla, the inhibition zones produced by all forest honey from Timor Island were higher than that of the commercial honey ( $8 \mathrm{~mm})$, but lower than that of antibiotics $(16.5 \mathrm{~mm})$. Thus, all types of forest honey from Timor island are potential to be considered as antibacterial against A. hydropilla and V. alginoliticus. The bigger the inhibition zone produced by the honey is, the higher the antibacterial activity.

Comparing among honey types from Timor Island, the highest antibacterial activity against $V$. alginolitycus was found in the forest honey from Naikliu (13 mm), while the highest antibacterial activity against A. hydropilla was found in the forest honey from Kefa $(12 \mathrm{~mm})$. It reveals that the antibacterial activity of each honey is different depending upon the type of honey, geographic position, and flower where the end product comes (Rio et al., 2012).

The potential of antibacterial in the honey could result from several mechanisms, i.e. presence of radical hydrogen peroxide $\left(\mathrm{H}_{2} \mathrm{O}_{2}\right)$ compound that can kill the pathogenic microorganisms (Johnston et al., 2018; Nadhilla, 2014; Carina et al., 2014), high acidity of the honey to reduce growth and survival of the bacteria Johnston et al., 2018; Carina et al., 2014; Nadhilla, 2014; Erguder et al., 2008), high sugar content inhibiting the bacteria to grow and develop (Carina et al., 2014; Erguder et al., 2008), and presence of antibacterial organic compounds (Carina et al., 2014).

Antibacterial activity of forest honey has been proved by previous researchers. For pathogenic bacteria in human, forest honey can inhibit the growth of Staphylococcus aureus (Ma'ruf et al., 2018; Adeyemo et al., 2017; Nadhilla, 2014; Rio et al., 2012; Hegazi et al., 2017), Escherichia coli (Adeyemo et al., 2017; 


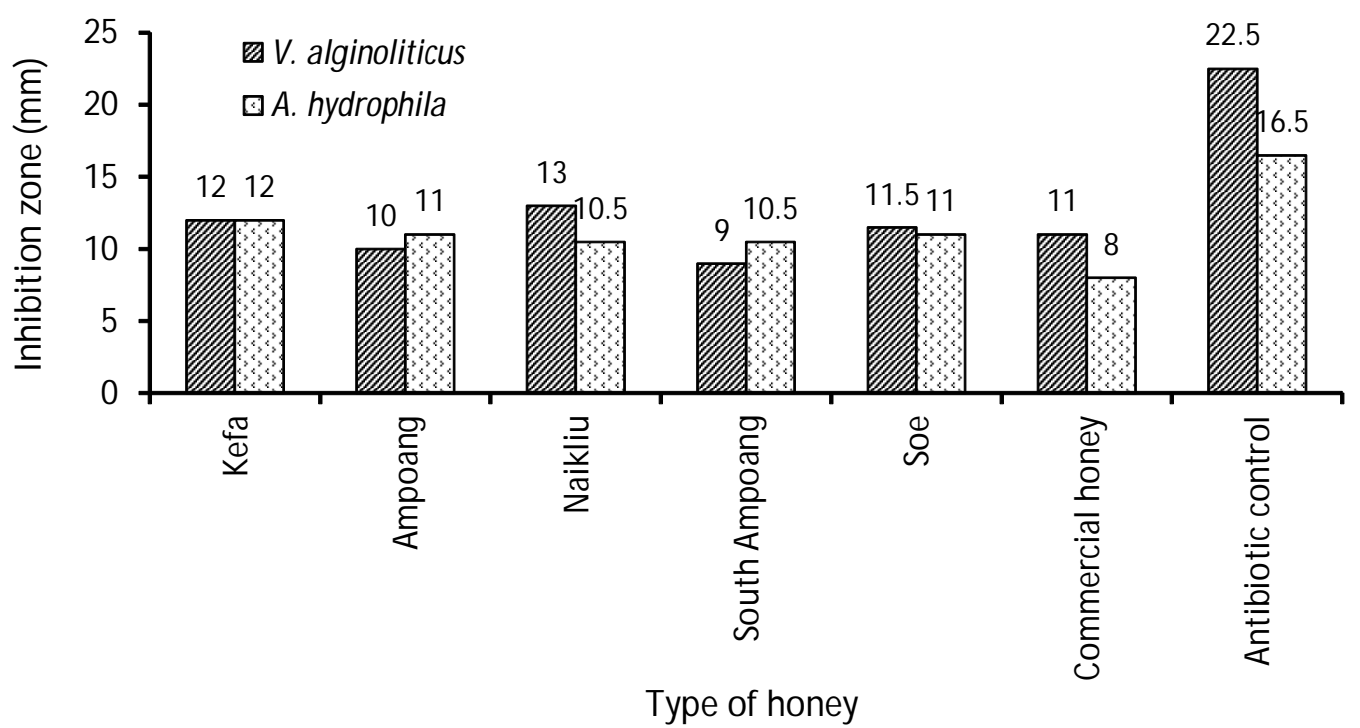

Figure 1. Antibacterial activity of forest honey from Timor Island against $\mathrm{V}$. alginoliticus and A. hydropilla.

Aurongze \& Azim, 2015; Rio et al., 2012; Hegazi et al., 2017), Salmonella typhi, Shigella Sonneie, Vibrio furnissii, Yersinia pestis, Campaylobecter jejuni (Aurongze \& Azim, 2015).

Antibacterial activity of forest honey against pathogens in fish is also shown by previous researchers. Stratev et al. (2015) has proved that rapa honey and royal jelly from Bulgaria are potential as an antibacterial against A. hydropilla. Ramalivhana et al. (2014) also found that honey from South Africa has antibacterial activity against A. hydropilla. Salosso (2017) reveals the antibacterial activity of Timor honey from Soe against A. hydropilla and V. alginolyticus.

\section{CONCLUSION}

Different forest honey from five areas in Timor Island contained alkaloid, saponin, steroid, and terpenoid, except that Kefa honey which did not hold steroid and terpenoid. The water content of all honey ranged from $15.70 \%$ to $26.65 \%$ total glucose $71.16 \%$ to $80.58 \%$ and pH 3.84 to 4.06 . It also had antibacterial activity against $A$. hydropilla and $V$. alginoliticus with different inhibition zones.

\section{ACKNOWLEDGEMENT}

The author would like to thank the Dean of the Faculty of Marine and Fisheries, Nusa Cendana, University Kupang, for his encouragement to do this study. My gratitude is also given to the Staff of Fish Quarantine Microbiology Labo ratory for their analytical assistance which has made possible to finish this study one time.

\section{REFERENCES}

Adeyemo, R.O., Torimiro, N., Akinola, S.A., Lawal, S.K., Abolarinwa, T.O. \& Adewoye, W.O. (2017). Study on antibacterial efficacy of different honey types in South Western Nigeria against wound associated bacteria. Journal of Aphyterapy, 2(1), 15-19.

Aurongze, M. \& Azim, M.K. (2015). Antibacterial activity of natural honey against antibiotic-resistant bacteria. J. Biochem. Mol. Biol., 48(1),18-21.

Evahelda, E., Pratama, F., Malahayati, N., \& Santoso, B. (2017). Physical and chemical characteristics of honey from rubber tree nectarin Central Bangka Regency, Indonesia. Agritech, 37(4), 363-368 [in Indonesian].

Baroni, M.V., Arrua, C., Nores, M.L., Fayé, P., Díaz, M.D.P., Chiabrando, G.A., \& Wunderlin, D.A. (2009). Composition of honey from Córdoba (Argentina): Assessment of North/South Provenance by chemometrics. Food Chemistry, 114(1), 727-733.

Buba, F., Gidado, A., \& Shugaba, A. (2013). Analysis of biochemical composition of honey sample from North-East Nigeria. Journal of Biochemistry and AnaIytical Biochemistry, 2(3), 1-7.

Carina, L., Soledad, V., \& Marina, B. (2014). Antibacterial activity of honey: A review of honey around the world. Journal of Microbiology and Antimicrobials, 6(3), 51-56.

Chayati, I. (2008). Physicochemical characteristics of monoflora honey from Yogyakarta and Central Java. Agritech, 28(1), 1-7 [in Indonesian]. 
Dewi, M.A., Kartasasmita, R.E., \& Wibowo, M.S. (2017). Antibacterial activity tests on several types of Indonesian honey against Staphylococcus aureus and Escherichia coli. Kartika; Jurnal IImu Farmasi, 5(1), 27-30 [in Indonesian].

Erguder, B.I., Kilicoglu, S.S., Namuslu, M., Kilicoglu, B., Devrim, E., Kismet, K. \& Durak, I. (2008). Honey prevent hepatic damage induced by obstruction of the common bileduct.World J. Gastroenterol, 12(23), 3729-3732.

Fitrianingsih, S.P., Khairat, A., \& Choestrina, R. (2014). Antibacterial activity of bitter honey and sweet black honey against Escherichia coli and Staphylococcus aureus. Jurnal Farmasi Galenika, 01(02), 3237 [in Indonesian].

Fadhmi, Mudatsir, \& Syaukani, E. (2015). Inhibility comparison of Seulawah honey and Trumon honey against Staphylococcus aureusin vitro. Jurnal Biotik, 3(1), 9-14 [in Indonesian].

François, E.A., Armand, P., Bertin, G., Victorien, D., Haziz, S., Durand, D-N.M., Esther, D., \& Lamine, B.M. (2017). Chemical screening and antibacterial activity of hone produced in Benin. Indian Journal of Science and Technology, 10(28), 1-11. DOI: 10.17485/ijst/2017/v10i28/112179.

Gulfraz, M., Ifftikhar, F., Asif, S., Raja, G.K., Asad, M.J., Abbasi, K., \&Zeenat, A. (2010). Quality assessment and antimicrobial activity of various honey types of Pakistan. African Journal of Biotecnology, 9(41), 6902-6906.

Hanani, E. (2014). Phytochemical analysis. Jakarta: Buku Kedokteran EGC, 262 pp [in Indonesian].

Hegazi, G.A., Al Guthami, F.M., Al Gethami, A.F.M., Abd. Allah, F.M., Saleh, A.A., \& Fouad, E.A. (2017). Potential antibacterial activity of some Saudi Arabia honey. Veterinary World, 10, 233-237. DOI: 10.14202/vetworld.2017.233-237.

Johnston, M., McBride, M., Dahiya, D., OwusuApenten, R., \& Nigam, P.S. (2018). Antibacterial activity of Manuka honey and its components: An overview. AIMS Microbiology, 4(4), 655-664.

Ma'ruf, M., Mawaddah, G.A., Eriana, N.N.A., Swari, F.I., Aslamiah, S., \& Lutpiatina, L. (2018). Honey of Kelulut bees (Trigona spp.) in activity against resistant-Staphylococcus aureus. Jurnal Skala
Kesehatan Politeknik Kesehatan Banjarmasin, 9(1), Januari 2018.

Nadhilla N.F. (2014). The activity of antibacterial agent of honey against Staphylococcus aureus. Artikel Review. Jurnal Majority, 3(7), 94-101.

Nayik, G.A. \& Nanda, V. (2015). Physico-chemical, enzymatic, mineral, and colour characterization of three different varieties of honey from Khasmir valley of India with a multivariate approach. Polish Journal of Food and Nutritions Sciences, 65(2), 101108.

Parwata, I M.O.A., Ratnayani, K., \& Listya, A. (2010). Anti-free radical and beta-carotene content in randu (Ceiba pentandra) honey and kelengkeng (Nephelium longata L.) honey. Jurnal Kimia, 4(1), 54-62 [in Indonesian].

Ramalivhana, J.N., Obi C.L., Samie, A., Iweriebor, B.C., Uaboi-Egbenni, P., Idiaghe, J.E., \& Momba, M.N.B. (2014). Antibacterial activity of honey and medicinal plant extracts against Gram negative microorganisms. African Journal of Biotechnology, 13(4), 616-625.

Rio, Y.B.P., Djamal, A., \& Asterina. (2012). Comparison of antibacterial effect of Sikabu honey and Lubuk Minturun honey against Escherichia coli and Staphylococcus aureus in vitro. Jurnal Kesehatan Andalas, 1(2), 59-62 [in Indonesian].

Stratev, D., Vashin, I., Balkanska, R., \& Dinkov, D. (2015). Antibacterial activity of royal jelly and rape honey against Aeromonas hydrophila (Atcc7965). Journal of Food and Health Science, 1(2), 67-74.

Salosso, Y. (2017). Antibacterial activity of Timor honey against Aeromonas hydropilla and Vibrio alginolyticus. Jurnal Media Exacta, Edisi April 2017 [in Indonesian].

Veeraputhiran, V., Maribah, T.P.E., \& Alfred, A. (2013). Physicochemical comparison and preservative of flora and non flora Honey. Agricultur and Food Science, 3(3), 128-130.

Yuliati. (2017). Efectivity test of honey solution as antibacterial against the growth of Staphylococcus aureus and Pseudomonas aeruginosae with disk diffusion method. Jurnal Profesi Medika, 11(1) Januari-Juli [in Indonesian]. 